\title{
ЗАСТОСУВАННЯ КІЛЬКІСНИХ ТА ЯКІСНИХ МЕТОДІВ ДЛЯ ОЦІНКИ РИЗИКІВ БУДІВЕЛЬНО-ІНВЕСТИЦІЙНИХ ПРОЕКТІВ
}

Казакова Н.А., к.е.н., завідувач кафедри міэнародних економічних відносин (ХНУ ім. В.Н. Каразіна)

Прав Ю.Г., к.е.н., заслужений економіст України, віце-президент (Всеукраӥнська громадська організація "Гільдія інженерів технічного нагляду за будівництвом об'єктів архітектури»)

Марушева О.А., к.ю.н., радник з юридичних та міжнародних питань (Громадська спілка «Міждержсавна гільдія інженерів консультантів») Шолом А.С., викладач (ХНУ ім. В.Н. Каразіна)

У статті висвітлені теоретичні аспекти поняття "ризик», його основні елементи та класифікації. У ході аналізу було виявлено, щзо якісний підхід можна використовувати скоріше для попередньої оцінки проектів, виявлення можливих видів ризиків $і$ опису джерел їх виникнення. Найбільш ефективні рішення з управління ризиком можна прийняти тільки за умови використання комплексного підходу.

Ключові слова: ризик, методи оцінки ризиків, інвестиційно-будівельні проекти, ризик-менеджмент.

\section{ПРИМЕНЕНИЕ КОЛИЧЕСТВЕННЫХ И КАЧЕСТВЕННЫХ МЕТОДОВ ДЛЯ ОЦЕНКИ РИСКОВ СТРОИТЕЛЬНО- ИНВЕСТИЦИОННЫХ ПРОЕКТОВ}

Казакова Н.А., к.э.н., доцент, заведующая кафедры международных экономических отночений (ХНУ им. В.Н. Каразина)

Прав Ю.Г., к.э.н., заслужсенный экономист Украины, вице-президент

(Всеукраинская общественная организация «Гильдия инженеров

технического надзора за строительством объектов архитектуры»)

Марушева А.А., К.ю.н., советник по юридическим и международным вопросам (Общественный союз «Межсгосударственная гильдия инженеров консультантов»)

Шолом А.С., преподаватель (ХНУ им. В.Н. Каразина)

B статье освещуень теоретические аспекты понятия «риск», его основные элементы и классификации. В ходе анализа было выявлено, что качественный подход можно использовать скорее для предварительной оченки проектов, выявление возможных видов рисков и описания источников их возникновения. Наиболее эффективные решения по управлению риском можно принять только при условии использования комплексного подхода.

Ключевые слова: риск, методы оценки рисков, инвестиционно-строительные проекты, риск-менедэммен.

(C) Казакова Н.А., Прав Ю.Г., Марушева O.А., Шолом А.C.

Вісник економіки транспорту і промисловості № 61, 2018 


\title{
APPLICATION OF QUANTITATIVE AND QUALITATIVE METHODS FOR ASSESSING RISKS OF CONSTRUCTION AND INVESTMENT PROJECTS
}

\author{
Kazakova N.A., Candidate of Economic Sciences, Head of Department of \\ International Economic Relations (V.N. Karazin KhNU) \\ Prav Yu.G., Candidate of Economic Sciences, Honored Economist of Ukraine, \\ Vice-President (All-Ukrainian NGO "Guild of Engineering Supervisors for the \\ Construction of Architectural Objects") \\ Marusheva O.A., Candidate of Legal Sciences, Adviser on Legal and \\ International Issues (Public Union "Interstate Guild of Consultants Engineers") \\ Sholom A.S., lecturer (V.N. Karazin KhNU)
}

An assessment of the project's effectiveness occurs, as a rule, in the context of uncertainty: cash flows refer to future periods, so they have a predicted, non-deterministic character. Thus, the current trends in the development of the market determine construction as an area of high risk, which, in turn, requires increased attention from investors. The article is concerned with the theoretical aspects of the concept of "risk", its main elements and classifications. The article includes an overview and analysis of existing qualitative as well as quantitative methods for project risk assessment. The analysis showed that a qualitative approach can be used only for preliminary evaluation of projects, identifying possible types of risks and describing the sources of their occurrence. It has been found that complete assessment of the magnitude and probability of possible losses, as well as effective risk management decisions can only be made using an integrated approach.

Keywords: risk, methods of risk assessment, investment and construction projects, risk management.

Постановка проблеми. Оцінка ефективності проекту відбувається, завжди в умовах невизначеності: потоки грошових коштів відносяться до майбутніх періодів, тому мають прогнозний, недетермінований характер. В умовах нестабільності зовнішнього середовища невизначеність проекту зростає, а ризики в сфері будівництва збільшуються, при цьому їх нормальний рівень значно вище в порівнянні 3 ризиками інших галузей економіки. Це можна пояснити такими інвестиційними характеристиками будівельних проектів, як низька ліквідність незавершеного будівництва, неможливість переміщення об'єкта будівництва, тривалі терміни створення тощо. Таким чином, сучасні тенденції розвитку ринку визначають сферу будівництва як область підвищеного ризику, що, в свою чергу, вимагає посилення уваги 3 боку інвесторів. Незалежно від характеру інвестицій, необхідною умовою довгострокового розвитку компанії $\epsilon$ доходи, що перевищують вартість витрачених ресурсів 3 урахуванням їх найкращого альтернативного використання. Ефективне, своєчасне вкладення капіталу в проект веде до досягнення нового рівня прибутковості, підвищення вартості та конкурентоспроможності компанії. I навпаки, інвестиції в проект, ризики якого виявилися недооцінені, можуть в майбутньому негативно позначитися на фінансових результатах і стійкості компанії.

Аналіз останніх досліджень i публікацій. Кількісні та якісні методи

Вісник економіки транспорту і промисловості № 61, 2018 
оцінки ризиків та особливості їх застосування розглядаються у працях вітчизняних і зарубіжних вчених, зокрема Авдошин С., Песоцька О. [1], Газарян Р. [2], Грачова М. [3], Зав'ялова Є. [4], Іванов А., Олейнікова С. [5], Кобильов А., Лачин Ю. [6], Лімітовський М., Мінасян В. [7], Попова Т. [8], Смоляк С. [9], Шапкін А. [10], Шарп У. [11], Шевцова Ю. [12], Хаффман Ф. [13], Хумпаісал С., Чен 3. [14], Лойзу П. [15], Мюррей С. [16]

Виділення невирішених частин загальної проблеми. Сфера будівництва $\epsilon$ однією 3 найбільш ризикованих. Незаплановані додаткові збитки в будівництві можуть виникати на кожному етапі реалізації проекту. Тому вкрай важливим $є$ з'ясування особливостей застосування кількісних та якісних методів саме у цій сфері для формування комплексного підходу для оцінки ризиків будівельно-інвестиційних проектів.

Метою статті $€$ з'ясування особливостей застосування кількісних та якісних методів для оцінки ризиків будівельно-інвестиційних проектів.

Виклад основного матеріалу дослідження. Можна виділити два основні підходи до визначення поняття «ризик». Відповідно до першого, ризик це ймовірність відхилення фактичного результату від очікуваного, або рівень невизначеності, який можна виміряти [11]. 3 іншого боку, також поширена точка зору, що ризик безпосередньо пов'язаний iз можливістю збитку. При цьому, під ризиком розуміється вимірювана частина невизначеності, яка тягне за собою можливість несприятливих наслідків виникнення збитків, недоотримання доходів або появи додаткових витрат за проектом. У той час, як поняття «невизначеність» має більш широкий зміст і може призводити не тільки до негативних, а й позитивних або нейтральних наслідки [3, 8]. Узагальнюючи різні інтерпретації цього поняття, можна виділити такі його основні елементи:
- невизначеність розвитку подій;

- можливість будь-яких (як негативних, так і позитивних) відхилень результату від передбачуваної мети;

- визначені ймовірності можливих результатів і очікувані результати [10].

Таким чином, проектні ризики в будівельній сфері можна визначити як кількісно вимірну ймовірність незапланованого недоотримання економічних вигод або виникнення додаткових збитків в рамках проекту, який прийнятий до реалізації або пов'язаний 3 ним діяльністю будівельної галузі. В цьому і полягає різниця між поняттями «невизначеність» i «ризик»: ризик настання тієї чи іншої події можна об'єктивно або суб'єктивно оцінити на основі розподілу результатів попереднього досвіду [15].

У той же час, iз самого визначення даного поняття виникає ймовірність недооцінки ризиків, що при несприятливому результаті i настанні ризикової події призводить до нестачі коштів для подальшого фінансування будівництва. Так, наприклад, якщо при плануванні грошових потоків для проекту, не в повній мірі був врахований ринковий ризик, зниження ціни за квадратний метр будівництва, тощо, то з настанням спаду на ринку нерухомості компанія, яка реалізує проект, буде відчувати брак коштів. Згодом це може призвести не тільки до «заморожування» будівництва об'єкта на невизначений термін, а й фінансової неспроможності всієї компанії і навіть банкрутства. Саме тому важливо встановити джерело виникнення потенційного чинника ризику, що неможливо без проведення аналізу основних класифікацій проектних ризиків в сфері будівництва.

Класифікація

ризиків інвестиційного проекту, як і будь-яка класифікація, досить умовна, тому існує безліч підходів до поділу видів ризику на групи. Це може бути виправдано тим, що для проектів 3 різних сфер економіки

Вісник економіки транспорту і промисловості № 61, 2018 
можна виділити специфічні, індивідуальні ризики. Однією з класифікацій ризику для будь-якої галузі $є$ їх поділ на основі впливу факторів, таких як соціальні, технологічні, економічні, політичні і факторів навколишнього середовища STEEP-фактори [14]. Ця класифікація актуальна і для будівельної діяльності, яка може бути сильно схильна до їх впливу, але вона не відображає усієї специфіки галузі.

Так, наприклад, Ф. Хафман робить акцент на специфічних зовнішніх ризиках і зазначає, що для реалізації проектів по будівництву об'єктів нерухомості особливо важливо враховувати фінансові, фізичні і регулятивні ризики. Фізичні ризики він пов'язує як безпосередньо 3 будівельним майданчиком, так і 3 можливими помилками при проектуванні, які можуть бути викликані поганою комунікацією між учасниками проекту (підрядниками, інвесторами, інженерамирозробниками). Регуляторні ризики будівельна компанія несе в зв'язку 3 контролем з боку місцевої влади, а також внаслідок зміни законодавства, регламентів або інструкцій [13].

Оцінюючи ризики інвестування в нерухомість, можна дійти до висновку, що ризик несе в собі дві складові систематичну і несистематичну (табл. 1). Імовірність або наслідки систематичного зовнішнього - ризику оцінити практично неможливо, тоді як несистематичний ризик можна як аналізувати, так i контролювати його причини і наслідки.

Класифікація ризиків будівництва та експлуатаиії споруд

\begin{tabular}{|l|l|}
\hline \multicolumn{1}{|c|}{ Систематичні ризики } & \multicolumn{1}{c|}{ Несистематичні ризики } \\
\hline Ринкові (зміни ринкових умов) & $\begin{array}{l}\text { Діловий (пов'язаний із бізнес процесами } \\
\text { організації) }\end{array}$ \\
\hline $\begin{array}{l}\text { Циклічний (пов'язаний із фазами } \\
\text { економічного зростання) }\end{array}$ & $\begin{array}{l}\text { Фінансовий (пов’язаний із фінансовою } \\
\text { незалежністю та стабільністю організації) }\end{array}$ \\
\hline $\begin{array}{l}\text { Інфляційний (зміни } \\
\text { платоспроможності покупців) }\end{array}$ & $\begin{array}{l}\text { Ризик ліквідності (незавершене будівництво } \\
\text { завжди має невисоку ліквідність) }\end{array}$ \\
\hline $\begin{array}{l}\text { Відсотковий (зміни умов } \\
\text { кредитування) }\end{array}$ & Інші специфічні ризики \\
\hline
\end{tabular}

Вивчивши загальноприйняті ознаки класифікації проектних ризиків, представляється доцільним їх поділ відповідно до етапів проектної діяльності: ризики передінвестиційної, інвестиційної (будівельної) та експлуатаційної (операційної) фази. При цьому ризики кожного 3 періодів підрозділяються на зовнішні - залежні від зовнішнього середовища, і внутрішні - визначаються діяльністю компанії-ініціатора.

В силу специфіки зовнішнього, інституційного середовища та організації фінансування об'єктів будівництва ризики на кожному етапі будуть відрізнятися від ризиків інших проектів, наприклад, проектів капітальних вкладень. Після ідентифікації ризиків конкретного проекту, необхідно провести їх аналіз, на основі якого буде прийматися рішення про доцільність участі у проекті. у загальному випадку виділяють два підходи до дослідження проектних ризиків - якісний і кількісний. Якісний підхід передбачає опис усіх передбачуваних ризиків проекту i ïx причин, оцінку їх наслідків, а також заходів щодо їх зниження [3].

В ході якісного аналізу визначаються фактори ризику, які можуть призвести до можливих втрат, а також їх

Вісник економіки транспорту і промисловості № 61, 2018 
ймовірність i час появи. Проводиться розрахунок максимальної величини втрат у разі найгіршого сценарію, а також ймовірність його реалізації. Серед якісних методів оцінки будівельно-інвестиційного проекту можна виділити:

1. Методи експертних оцінок.

Ця група методів $\epsilon$ комплексом логічних i математико-статистичних методів i процедур аналізу ризиків, заснованих на висновках експертів, які мають досвід реалізації подібних проектів. Кожному експерту у вигляді опитувальних листів надається вичерпний перелік ризиків та пропонується оцінити ймовірність їх настання за спеціальною шкалою. Серед них виділяють: метод Дельфі, метод бальної оцінки та його аналоги, методики ранжирування, зокрема рейтинговий метод, тощо [4].

У процесі дослідження за методом Дельфі виключається спілкування між експертами та проводиться їх анкетування 3 метою з'ясування їх думки 3 приводу майбутніх гіпотетичних подій. Експерти відповідають на питання у вигляді кількісних оцінок ризику самостійно i анонімно, потім вони можуть коригувати свої думки з урахуванням загальної думки експертів. Групова оцінка може проходити в кілька турів [5].

Метод бальної оцінки ризику проводиться на основі узагальнюючого показника, що визначається по ряду приватних експертно оцінюваних показників ступеня ризику. Він складається з наступних етапів:

1) визначення факторів, які впливають на виникнення ризику;

2) вибір узагальненого показника i набору приватних критеріїв, що характеризують ступінь ризику по кожному з факторів;

3) складання системи вагових коефіцієнтів і шкали оцінок за кожним показником (фактору);

4) інтегральна оцінка узагальненого критерію ступеня проектних ризиків;
5) вироблення рекомендацій 3 управління ризиком [2].

Розглянувши основні принципи проведення якісної оцінки ризиків, потрібно відзначити, що на практиці ці методи можуть бути застосовні тільки в сукупності з іншими, більш об'єктивними (кількісними) методами. По-перше, зростає ризик необ'єктивності результатів через неякісний підбор експертів, їх недостатньої кваліфікації, домінування думок або навіть помилок методичного характеру. По-друге, ці методи не враховують той факт, що настання однієї ризикової події може провокувати втрати різних видів i негативно впливати на результат за проектом відразу в декількох аспектах [16]. Саме ці фактори обмежують застосування експертних методів при оцінці ризиків в будівництві нерухомості. Вони можуть бути використані на початковій стадії аналізу, наприклад в ході первинного визначення ризиків проекту: експертами може бути складена матриця ймовірних загроз (зниження ціни за квадратний метр, ризик неотримання або відкликання дозвільної документації, виникнення помилок при проектуванні або аварійної ситуації тощо). Згодом результати опитування експертів можуть бути використані в ході кількісного аналізу (наприклад, аналізу чутливості) i підсумкова оцінка за проектом буде виноситися на основі більш об'єктивних чинників.

2. Аналіз доцільності (доречності) витрат і метод аналогій.

В основі аналізу доречності витрат лежить припущення про те, що перевитрата коштів (негативний результат, характерний для ризику) може бути викликана наступними факторами:

- вартість реалізації проекту в цілому або його окремих фаз спочатку була недооцінена;

- фактична продуктивність машин (механізмів) не дорівнює плановій; - фактичні норми витрат відрізняються від планових через

Вісник економіки транспорту і промисловості № 61, 2018 
непередбачені зміни зовнішніх факторів (інфляція, зміни податкового режиму тощо).

В ході аналізу складається контрольний постатейний перелік можливого підвищення витрат для проекту. Фінансування проекту розбивається на стадії, тому, при перших ознаках того, що ризик вкладення зростає, інвестор може вжити заходів щодо зниження витрат або припинити фінансування проекту.

Метод аналогій передбачає оцінку ризику на основі аналізу даних аналогічних, в тому числі і за ступенем ризику, проектів. Ними можуть бути реалізовані в минулому проекти компаніїініціатора або аналогічні проекти компаній конкурентів. Складність при використанні цього методу полягає в правильному підборі аналога, так як формальні критерії, що дозволяють встановити ступінь аналогічності ситуацій, на практиці відсутні [3].

Крім того, ігнорується і той факт, що будь-який вид діяльності і зовнішне середовище проекту постійно розвиваються. Також відсутні методичні рекомендації, які докладно описують логіку і деталі подібної процедури оцінювання ризику.

При оцінці проекту будівництва нерухомості, метод аналогій досить легко реалізується, якщо компанія має досвід будівництва подібних об'єктів. На підставі статистичного матеріалу вже реалізованих проектів, у яких виникли незаплановані витрати можна встановити область ризику нового проекту [5, с.108]. Як і методи експертних оцінок аналіз доречності витрат i метод аналогій можна використовуватися скоріше для попередньої оцінки проектів. Їх можна назвати прийнятними для опису можливих ризиків, але не для отримання об'єктивної оцінки ризику. Для проектів будівництва нерухомості їх застосовність обмежує зокрема високий ступінь невизначеності майбутніх умов ринку: у цьому випадку метод аналогій не може вважатися об'єктивним, тому що вхідні потоки доходів від реалізації квартир, як і зміна середніх цін за квадратні метри, не можуть бути визначені однозначно. Цим обумовлена необхідність застосування комплексного підходу 3 використанням якісного і кількісного аналізу, основні методи i алгоритми якого будуть розглянуті нижче.

Як було зазначено вище, найбільш повно і об'єктивно оцінити величину i ймовірність можливих збитків можна 3 використанням методів кількісного аналізу, який передбачає присвоєння кількісного параметра якісному. В ході кількісної оцінки ризиків визначаються окремі види ризику, ймовірність настання тих чи інших подій, а також розраховуються показники, що кількісно характеризують ступінь ризику. Кількісна оцінка відображає величину передбачуваного ризику по проекту, його реальна величина набуває розголосу в результаті факту настання ризикової події. В якості найбільш поширених інструментів кількісної оцінки проектних ризиків виділяють метод коригування норми дисконту.

Невизначеність умов реалізації проекту при визначенні очікуваного ефекту (NPV) в розрахунках може включатися в ставку дисконтування як поправка на ризик. У разі реалізації проекту будівництва нерухомості можна розглядати такі поправки [9]:

1) Ризик ненадійності учасників проекту - можливість непередбаченого припинення або призупинення реалізації проекту в силу різних обставин, таких як:

- нецільове витрачання коштів, передбачених для інвестування в проект або створення резервів, необхідних для його реалізації;

- фінансова нестійкість компанії, що реалізує проект, як наслідок недостатньої забезпеченості власними оборотними засобами або недостатнього майнового забезпечення по кредиту та ін.;

Вісник економіки транспорту і промисловості № 61, 2018 
- неплатоспроможність або нездатність виконувати свої зобов'язання в рамках укладених договорів інших учасників проекту - постачальників сировини, інших контрагентів або споживачів продукції.

Поправка за даний вид ризику визначається експертним шляхом кожним учасником проекту - i зазвичай не перевищує 5\%, однак іiі величина може варіюватися в залежності від ступеня опрацьованості механізмів організації і реалізації проекту. Зокрема, розмір премії може зменшуватися, якщо учасники надають будь-які майнові гарантії виконання зобов'язань, і збільшуватися, якщо учасники не мають інформації про надійність постачальників, потенційних покупців та ін.

2) Ризик неотримання передбачених проектом доходів або «несистематичний» ризик. Цей вид ризику може бути обумовлений як внутрішньої середовищем проекту (технічними, технологічними, організаційними рішеннями), так i зовнішнім оточенням - випадковими коливаннями обсягів виробництва, цін на ресурси (матеріальні, трудові) та продукцію. Розмір премії за такий ризик визначається для конкретного проекту, конкретної галузі та іiі стадії життєвого циклу. Зазвичай поправки роблять на новизну використовуваної техніки (технологіï), циклічність попиту на продукцію i інші чинники, визначаючи величину премії в розмірах $1-3 \%$ i підсумовуючи їх вплив [9].

Зазначений підхід розрахунку ставки дисконту з поправкою на ризик $\epsilon$ дещо суб'єктивним i не враховує кореляцію факторів між собою. Крім того, дисконтування за вищою нормою не дозволяє врахувати можливі відхилення результатів проекту, і отримані результати істотно залежать тільки від величини премії за ризик. Даний метод також передбачає збільшення ризику в часі 3 постійним коефіцієнтом, що обмежує його застосування в рамках оцінки проектів будівництва. Пропорційне збільшення ризику до кінця інвестиційної фази не може бути коректним, так як для таких проектів навпаки характерним $\epsilon$ поступове зниження ризику 3 ростом готовності будинку. Так, прибуткові проекти, що не припускають істотного збільшення ризику 3 плином часу, можуть бути проаналізовані невірно і відхилені.

2. Метод аналізу чутливості та критичних значень.

Цей метод аналізу ризиків полягає в дослідженні залежності результуючого показника проекту від зміни якого-небудь одного параметра (при збереженні інших на незмінному рівні). В якості результуючих показників зазвичай розглядають показники ефективності (NPV, IRR, PI, PP) або щорічні показники проекту (розмір чистого, накопиченого прибутку). Проведення аналізу передбачає наступні етапи:

- математично визначається
взаємозв'язок між вихідними i
результуючим показником;
- визначаються найбільш ймовірні
значення для вихідних показників і
діапазони їх змін (зазвичай в межах 5-
$10 \%)$;

- розраховується найбільш ймовірне значення результуючого показника;

- досліджувані вихідні параметри по черзі змінюються в допустимих межах, визначаються нові значення результуючого критерію;

- вихідні параметри ранжуються за ступенем впливу на зміну результуючого показника, таким чином відбувається їх угруповання в залежності від ступеня ризику.

Аналіз також можна провести графічно, побудувавши залежності результуючого показника від зміни кожного 3 чинників. Чим більше кут нахилу залежності, тим більше ризик i чутливіші значення результату по проекту до зміни параметра. На підставі цих розрахунків далі проводиться ранжування факторів за ступенем важливості (висока,

Вісник економіки транспорту і промисловості № 61, 2018 
середня, низька) i будуються матриці чутливості.

Продовженням цього методу $\epsilon$ метод критичних точок (перевірки стійкості проекту), який грунтується на визначенні значень змінних ризикфакторів, які призводять результуючий показник за проектом до критичної межі. Розробляються найбільш ймовірні і критичні сценарії поведінки вихідних показників і величини можливих втрат [6]. При цьому проект можна вважати стійким i ефективним, якщо в модельованих ситуаціях NPV проекту є позитивним i забезпечується необхідний резерв його фінансової можливості бути реалізованим [16].

Незважаючи на очевидні переваги цих методів - об'єктивність, наочність результатів, багато авторів виділяють і головний їх недолік - передумова, що зміна факторів проводиться ізольовано, в той час як на практиці вони можуть бути корельовані [16]. Для проектів у сфері будівництва це може мати визначальне значення: в період спаду ринку нерухомості та економіки багато чинників $\epsilon$ взаємозалежними. Так, наприклад, може спостерігатися падіння середніх цін на нерухомість (ринковий ризик), в той час як процентна ставка буде рости, змінюючи умови кредитування (процентний ризик), що спричинить за собою ризик перевищення кошторисної вартості будівництва і несвоєчасного завершення робіт. У цьому випадку, якщо змінні тісно взаємопов'язані, необхідно розглядати їх можливі комбінації i використовувати сценарний аналіз, який являє собою розвиток методики аналізу чутливості та одночасної зміни піддається уся група чинників, що перевіряються на ризик.

3. Метод дерева подій (рішень).

Цей інструмент аналізу передбачає побудову мережевого графіка, кожна гілка якого відображає альтернативні варіанти розвитку або стану середовища [8]. Так, слідуючи уздовж гілок дерева, можна простежити усі варіанти розвитку можливих подій, а також вибрати найменш ризикований і оптимальний. У загальному випадку його алгоритм можна представити у вигляді наступних етапів:

1) для кожного моменту часу визначається проблема (вершина) i можливі шляхи розвитку подій (вихідні дуги);

2) кожній дузі експертним методом задається ймовірність і грошова оцінка (можливі втрати);

3) 3 урахуванням значень всіх вершин розраховується найбільш ймовірне значення NPV або інший ключовий показник проекту;

4) проводиться аналіз імовірнісних розподілів.

В якості основних переваг цього методу можна виділити як можливість детального обліку багатьох факторів ризику, так i наочність, логічну послідовність виконуваних операцій. Практичне застосування «дерева подій» в рамках оцінки ризику проекту в будівництві бачиться так:

1) за допомогою аналізу чутливості визначаються найбільш серйозні фактори ризику;

2) експертно задається ймовірність ї реалізації;

3) малюються у вигляді графіку можливі сценарії зміни визначених факторів ризику в рамках відповідного діапазону;

4) для кожної вершини розраховується значення NPV;

5) проводиться ймовірнісностатистичний аналіз розподілу NPV проекту.

Такий комплексний підхід до аналізу ризиків у будівельній сфері дозволить мінімізувати недоліки кожного 3 використовуваних методів, якби вони використовувалися окремо. По-перше, підсумковий результат за проектом виноситься 3 урахуванням одночасної зміни усіх основних чинників ризику, що неможливо зробити тільки за допомогою аналізу чутливості. Так, можна не

Вісник економіки транспорту і промисловості № 61, 2018 
ізольовано оцінити вплив зміни прогнозних цін на нерухомість, ставки по кредиту i ризику перевищення кошторисних витрат. По-друге, береться до уваги якісна сторона оцінки - думка експертів, що дуже важливо для досягнення достовірної кількісної оцінки і обліку специфічних особливостей конкретного проекту.

4. Імітаційне моделювання.

Практичне застосування цього підходу на основі методу Монте-Карло демонструє широкі можливості його використання в інвестиційному проектуванні в умовах невизначеності i ризику, дозволяючи враховувати максимальну кількість чинників зовнішнього середовища. Алгоритм імітаційного моделювання можна представити таким чином:

1) на основі аналізу чутливості визначаються ключові фактори проекту, зміни яких призводять до найбільших відхилень результату по ньому (NPV);

2) експертною оцінкою або на основі статистичних даних задаються максимальне, мінімальне значення (діапазон змін) і розподіл ймовірностей по кожному чиннику;

3) багаторазово і випадковим чином проводиться імітація ключових чинників у рамках обраного розподілу, розраховуються відповідні значення NPV;

4) аналізується розподіл ймовірностей результуючого показника за проектом (математичне очікування NPV, дисперсія, середньоквадратичне відхилення тощо) [3].

На основі отриманої інформації можна розрахувати ймовірність отримання NPV у будь-якому діапазоні прийнятних для інвестора значень. Серед недоліків цього підходу виділяють такі: існування корельованих параметрів сильно ускладнює модель;

- вид імовірнісного розподілу для досліджуваного чинника іноді важко визначити;
- дослідження моделі можливо тільки при наявності обчислювальної техніки та спеціальних пакетів програм;

$$
\text { - у порівнянні } 3 \text { іншими }
$$
інструментами кількісного аналізу цей підхід може бути менш точним і давати більш оптимістичні оцінки через урахування проміжних варіантів зміни ознак [16].

Однак для формування об'єктивної оцінки ризику цей метод може бути дуже корисним: аналізуючи проект будівництва нерухомості, його можна використовувати 3 метою зниження упередженості оцінок експертів. Сценарії розвитку подій, розроблені на основі їх суб'єктивної думки, повинні бути модифіковані випадковим чином, щоб прибрати цю суб'єктивну складову прогнозу. Застосування даного методу передбачається як раз на етапі формулювання можливих результатів дерева подій. Так, наприклад, імітаційне моделювання можна використовувати для додання чинника випадковості прогнозам цін на ринку нерухомості, при цьому основні характеристики розподілу (розмах, середнє очікуване значення) не зміняться.

Таким чином, проведений вище аналіз джерел проектних ризиків показав, що незаплановані додаткові збитки в будівництві можуть виникати на кожному 3 етапів реалізації проекту передінвестиційній, інвестиційній або фазі експлуатації нерухомості. В силу нестабільності зовнішнього середовища уникнути ризиків практично неможливо, але можна детально оцінити ймовірні втрати якісно або кількісно. Всі розглянуті вище алгоритми мають свої недоліки i переваги: завданням якісного підходу можна назвати виявлення можливих видів ризиків і опис джерел їх виникнення, тоді як чисельну величину ймовірних втрат визначають кількісні методи. При аналізі інвестиційного проекту необхідно застосовувати комплексний підхід, для того щоб найбільш повно оцінити

Вісник економіки транспорту і промисловості № 61, 2018 
величину і ймовірність можливих збитків, a також приймати ефективні рішення 3 управління ризиком. Його алгоритм можна комбінувати з розглянутими вище аналізом чутливості, деревом рішень та імітаційним моделюванням Монте-Карло.

Висновок. У статті були висвітлені теоретичні аспекти поняття «ризик», його основні елементи та класифікації. Проектні ризики в будівельній сфері були визначені як кількісно вимірна можливість незапланованого виникнення додаткових збитків (недоотримання економічних вигод) в рамках проекту, що реалізовується, або пов'язаної 3 ним діяльності. Далі був зроблений огляд i аналіз існуючих методів оцінки ризиків проекту: якісних (метод експертних оцінок, аналогій, аналіз доречності витрат) i кількісних (метод коригування норми дисконту, розрахунку критичних точок, аналіз чутливості, імітаційне моделювання). В ході аналізу було виявлено, що якісний підхід можна використовувати для попередньої оцінки проектів, виявлення можливих видів ризиків і опису джерел їх виникнення. Ці методи можуть бути корисні для опису можливих ризиків, а не для отримання остаточної оцінки ризику для його порівняння з масштабами інвестиційного проекту.

Алгоритми методів кількісного підходу також мають свої недоліки і переваги, їх завданням можна назвати визначення чисельної величини ймовірних втрат - ступеня ризику. Так, було встановлено, що найбільш повно оцінити величину і ймовірність можливих збитків, a також приймати ефективні рішення 3 управління ризиком можна тільки за умови використання комплексного підходу. Це можна реалізувати за допомогою інтегрування описаних технік кількісного підходу - аналізу чутливості, дерева рішень та імітаційного моделювання Монте-Карло - в алгоритм сценарного аналізу ризиків.
Подальші дослідження доцільно зосередити на розробці комплексного механізму оцінки ризиків будівельноінвестиційних проектів.

\section{ПЕРЕЛІК ВИКОРИСТАНИХ ДЖЕРЕЛ}

1. Авдошин, С.М., Песоцкая, Е.Ю. Информационные технологии для управления финансовыми рисками // Бизнес-информатика. - 2011. - №1(15) . C. $42-49$

2. Газарян, Р. К. Риски в строительстве (виды, влияние и методы управления) // Сборник докладов международной научно-технической конференции студентов (15-19 марта 2010 г.). - М.: МГСУ, 2010. - С. 92-95

3. Грачева, М.В. Риск-менеджмент инвестиционного проекта; под ред. М.В. Грачевой. - М.: Юнити-Дана, 2009. - 544 c.

4. Завьялова, Е.Н. Оценка рисков инвестиционного проекта // Вестник ТГАСУ. - 2004. №1. - С.234-237

5. Иванов, А.А., Олейников, С.Я. Риск-менеджмент. - М.: Изд. центр ЕАОИ, 2008. - 193 c.

6. Кобилев, А.Г., Лачин, Ю.В. Оценка риска при планировании инвестиций на предприятии // Экономический Вестник Ростовского государственного университета. - 2008. №1. - C. 168-170

7. Лимитовский, М. А., Минасян, В. Б. Анализ рисков инвестиционного проекта//Управление финансовыми рисками. - 2011. - №2. - С. 132-150

8. Попова, Т. А. Определение понятия риска в рамках концепции приемлемого риска // Научные записки НГУЭУ. - 2008. - №4

9. Смоляк, С. А. О норме дисконта для оценки эффективности инвестиционных проектов в условиях риска//Аудит и финансовый анализ. -2000 . - C.134-147

10. Шапкин, А. С., Шапкин, В. А. Теория риска и моделирование рисковых

Вісник економіки транспорту і промисловості № 61, 2018 
ситуаций: Учебник. - М.: Издательскоторговая корпорация «Дашков и К», 2005. -880 c.

11. Шарп, У.Ф., Александер, Г. Дж., Бэйли, Дж. Инвестиции: Учебник. - М.: Инфра-М, 2001. - 1028 с.

12. Шевцова Ю.В. Методические подходы и практические приёмы операционного риск-менеджмента в телекоммуникационных компаниях// Вестник СибГУТИ. - 2009. - № 1. - С. 5266

13. Huffman, F. E. Corporate real estate risk management and assessment// Journal of Corporate Real Estate. -2002. - № 5(1). - Pp. 31-41

14. Khumpaisal, S., Chen, Z. Risk assessment in real estate development: an application of analytic network process//Journal of Architectural/Planning Research and Studies. - 2010. - №7(1).- Pp. 103-116

15. Loizou, P., French, N. Risk and uncertainty in development: A critical evaluation of using the Monte Carlo simulation method as a decision tool in real estate development projects//Journal of Property Investment \& Finance. - 2012. №30.- Pp. 198-210

16. Murray, S. L. Grantham, K. Development of a Generic Risk Matrix to Manage Project Risks // Journal of Industrial and Systems Engineering. - 2011. -№5(1). Pp. 35-51

\title{
УДК 330.341.1:656.2
}

\section{ІННОВАЦІЙНИЙ РОЗВИТОК ВАГОННОЇ ДІЛЬНИЦІ}

\author{
Назаренко І.Л., к.е.н., доцент, \\ Корчинська Н.В., слухач магістратури ІППК (УкрДУЗТ)
}

В статті на основі аналізу існуючих визначень терміну «інновачйний розвиток» визначено сутність інновачійного розвитку вагонної дільниці: ие иілеспрямований систематичний прочес позитивних змін якісного стану всіх ї̈ підсистем через впровадження інновачій (розроблених як зовнішніми, так і власними силами) в діяльність вагонної дільниці з метою досягнення як ичілей інноваційної діяльності, так і стратегічних цілей розвитку систем вищого рівня - вагонного господарства та ПАТ «Украйнська залізниия». дільниця

Ключові слова: інноваційний розвиток, залізничний транспорт, вагонна

\section{ИННОВАЦИОННОЕ РАЗВИТИЕ ВАГОННОГО УЧАСТКА}

\section{Назаренко И.Л., к.э.н., доцент, Корчинская Н.В., случатель магистратуры ИППК (УкрГУЖТ)}

В статье на основе анализа существующих определений термина "инновационное развитие" определена сущность инноваџионного развития вагонного участка: это иеленаправленный систематический процесс позитивных изменений качественного 